Article

\title{
Returning Faith to Knowledge: Earthlings after the Anthropocene
}

\author{
Whitney A. Bauman $\mathbb{D}$ \\ Department of Religious Studies, Florida International University, 11200 SW 8th St, Miami, FL 33199, USA; \\ wbauman@fiu.edu
}

Received: 10 March 2020; Accepted: 1 April 2020; Published: 4 April 2020

\begin{abstract}
The technologies of the Anthropocene are based upon Modern certainties. These technologies of a reductive and productive model of science create the worlds in which we live, in the image of a particular human being: the modern, western anthropos (with its raced, sexed, and gendered body). This article explores some of the technologies of the Anthropocene, and the environmental and social problems they give rise to. Finally, this article argues for the development of multiple planetary technologies based in uncertainty about the planetary future, that open humans onto more just and ecologically sound possibilities for planetary becoming.
\end{abstract}

Keywords: globalization; climate change; Anthropocene; planetarity

\section{Introduction}

The fact that the universe apparently generates the conditions for the emergence of ... civilizations (we are, in fact, here) tells us that, to the best of our guesses, we are part of a game of chance and of skill, a kind of cosmic evolutionary process, which in turn gives us a realistic hope that we might make it through. (Or not.) Realistically speaking, our chances are somewhere between abysmal and possible. So it makes sense to try. (Ivakhiv 2018, p. 96)

The language of the Anthropocene that has emerged over the past decade has several problematic aspects. First, it is used by those environmentally concerned, particularly with climate change, in a negative sense: there is nothing that is left untouched by human hands. At the same time, it is positively used by some transhumanists: the era of the human has arrived and we have gained the upper hand over nature. This is the first named geological era that has resituated the human as the locus of geological time and it is emotionally charged, rather than descriptive. Is this not just a re-staging of anthropocentrism in new clothes: whether we take it to be a positive or negative thing?

Second and related, the Anthropocene leaves humans with too much control. We are so powerful that we have brought about a new geological era, so why not geo-engineer the world further to create a different era? This is the hope of some transhumanists, who are frankly happy that humans are becoming more silicon, metallic and technological than flesh, tissue, and biologically rooted. In other words, is this not the era of the Anthropocene announcing that we have subsumed nature under human control? If this is the case then perhaps we just need more human technologies and engineering to "fix" the problems of climate change.

Third, the Anthropocene lumps all humans together as if there is equal responsibility for climate change across the globe. This is convenient nomenclature at a time when it has become clear that the fossil-fueled northern hemisphere (for the most part) is largely to blame for the current climate crisis. Not all people are equally responsible for mass extinctions, coral bleaching, and climate change. For this reason, some have argued that we call this era the capitolocene (though others point out that communism has not done better environmentally or socially). Others have argued that we 
name this period the fossil-fueled era (Moore 2016). In any event, the nomenclature "Anthropocene" levels humanity in a way that makes it easy for first world leaders to take issue with African, Latin American, South Asian, and South East Asian countries who argue that they were not the one's primarily responsible for resource extraction and thus, should not have to pay as much as wealthy countries in terms of mitigation and adaptation costs.

The leveling of humans to a common anthropos along with the perpetuation of the idea of human exceptionalism and/or anthropocentrism are, to say the least, problematic. When humanity is made "one," the most powerful among humans define what the normative human is: the colonizing subject rears its ugly head. From the perspective of the colonizing subject, humans ought to have the agency and certainty through science and technology to solve all social and ecological problems. Those human subjects who fail at this (for lack of resources due to various oppressions) are seen as less than, dangerous, criminal, pitiable, or as charity cases by those who most match up to the ideal colonizing subject. Furthermore, those who base knowledge claims outside of modern western modes of knowledge (reason, objectivity, science, and still sometimes Christianity) are seen as in need of education, enlightenment or development. Polytheists, Muslims, animists, and "others," that fall outside the single tunnel of western Modernity must all be ranked as less than the western modern (Mignolo 2011).

From this anthropic, modern, certain perspective, there is no need for faith and hope: the certainty of Modernity does not require it. The certainty of Modernity requires only that everyone and everything comply or consent to its logic. What if, instead of projecting this certainty onto an indefinite future in which the anthropos will be at the center, we begin to live once again in hope and faith toward something different? What if, instead of recreating the world for the anthropos thorough technologies of certainty, we develop instead uncertain technologies for the entire planetary community? Instead of using science, technology, and religion to create the world in the image of a certain ideal of humanity, what if we used science, technology and religion to co-create a flourishing and more just planetary community?

As the epigram to this article suggests, maybe the fact that we are here has nothing to do with telos or foundations laid down "in the beginning". Instead, maybe it is a game of "chance and skill" played with the evolving planetary community. From this latter perspective, it may be possible to live in faith and hope with the planetary community for a more just and flourishing future. In this brief article, I describe some of what I call the technologies of certainty and how these technologies of certainty create violence to earth bodies (human and non). These are essentially the tools of western colonization used by the Greeks/Romans, Christians, and then the proponents of European western Enlightenment. These are all technologies of certainty that maintain the center of power for the status quo. In the second part of this article, I describe technologies for what I am calling a Critical Planetary Romanticism (CPR) for planet Earth. These technologies emerge from and hold open spaces of uncertainty, spaces of otherness, spaces for new possibilities to emerge. It is from these spaces and with these technologies that I think hope and faith for a more just, equitable, and flourishing planetary future might emerge.

Before I begin with these two main sketches of the technologies of certainty and uncertainty, I start with a narrative that locates my own subjectivity. This narrative approach is important because narratives allow people to make connections (intellectually, personally, and affectively) in ways that trip up the idea that ideas and knowledge are merely objective, linear, rational, and logical. So, I begin here with my own eco-socio-cultural location to help attune the reader to my arguments.

\section{From Uncertainty to Certainty: The Story of One Family Farm}

Figure 1 is my family's old farm. I lived in that little house in the front left corner as a baby and I grew up playing on that farm, helping out with our family garden plot, shucking corn and hulling peas, riding in combines with my grandfather, and hunting and fishing in many different wooded areas and reservoirs that made up that unique landscape. All of this gave me embodied knowledge about human-earth relations: predator-prey relations, the importance of "listening" to the land, the type of 
"balance" that one had to make in terms of how much land should be under production at any given time, etc. It also gave me a sense of what it meant to live in faith and hope. Every year, farmers take out loans for the crop they are putting in the ground in hopes that the yield will be enough to make a profit. This is not guaranteed, and it takes the cooperation of many different entities within the natural world to make it happen. This cooperation-between humans and the rest of the natural world-was something that was always open-ended (never certain). Furthermore, we were a part of this unique landscape and ecosystem. Nature was, then, never for me a wilderness devoid of human life, nor was it just a mere resource for human projects: rather, we are a part of nature and whatever culture, language, and human knowledge and technologies are, I grew to understand them as part of nature as well.

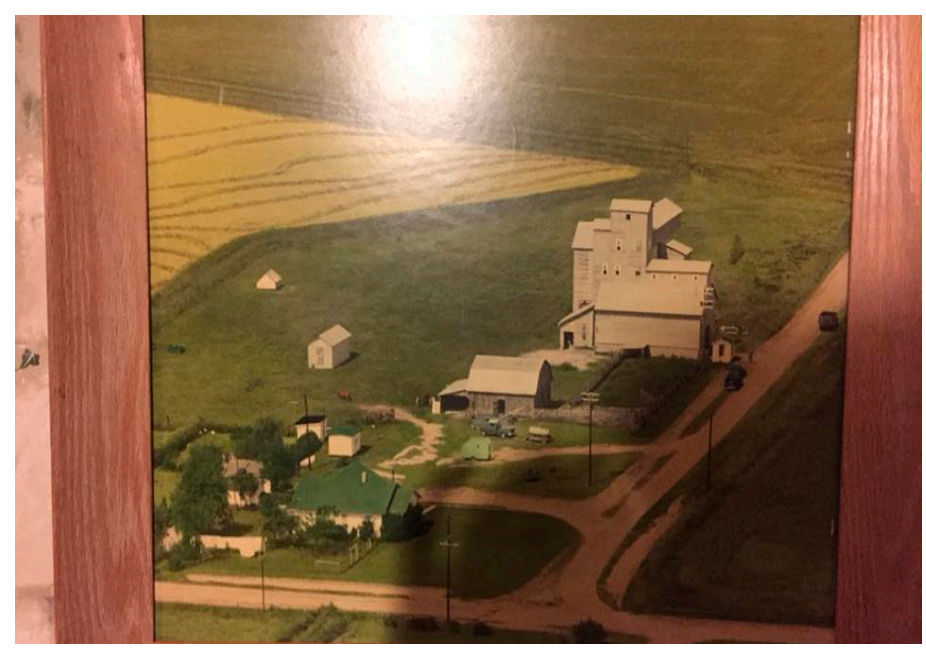

Figure 1. The Goodwin-Bauman Family Farm.

During the 1980s as some readers will recall, the deregulation by the Reagan administration put huge strains on smaller family farms like ours. Under economic pressures, I watched over a period of 10 to 15 years as this farm changed from a multiple-use farm (hunting, fishing, rotating crops of corn, soy, rice, sunflowers, and milo, mostly, along with areas for family garden plots) to mono-cropped Monsanto soybeans. The forested areas where we went hunting were cut down for more production area, and the reservoirs were not maintained as an ecosystem (with a focus on game and wildlife) but were turned into mere sources of water for the crops. This is an example of the reductive-productive model that I critique in this article, along with its underlying assumptions about truth, nature, and the role of human beings on the planet. The transformation of my family farm by this reductive and productive model is a microcosmic experience of what living in the Anthropocene is like. I will come back to this personal story at the end of this article. Here, I start describing some technologies of the reductive-productive model that I think are imported into the modern scientific narrative from its roots in monotheism, and especially Christian theology: chronological time, an understanding of causality as efficient, and human exceptionalism.

\section{Technologies of Certainty (Nationalism/Neoliberal Globalization): The Mechanized Organism (Enframement)}

When I use the word "technology" throughout this article, I mean it in the broader Ancient Greek sense, which can mean language, ideas, art, and anything that helps shape the material world around us. Accordingly, I include religious ideas here. Technology is, in this sense, part of being human. Technology is not limited to human persons, but human persons seem to rely on it to inhabit the world to a greater extent than any other persons or beings on the planet that we know of (for better and for worse). Technologies in this broad sense shape the becoming of earth bodies in different ways (both good and bad). Here, I examine three of the technologies that have helped to create the mechanized organism that we now call "The Anthropocene": chronological time, the reduction of causality to 
efficient causality (which is another way to talk about isolated agency), and essentialism (which supports human exceptionalism to the rest of the natural world). These are not the only technologies I could refer to, but they are important ones.

\subsection{Chronological Time: The Fossil Fueled Tunnel of Time}

Chronological time produces anxiety because it places all of our thinking into an abstract sense that is literally "out of this world" and "out of this universe." Chronological time, an abstraction, becomes more important than immediate and present relationships and our embodiments in the world. In a world sped up by fossil fuels, the abstraction of time creates a pace of progress that far outstrips the regenerative capacities of the planet, which evolved at their own pace and have no regard for our abstractions. The pace of contemporary, industrialized life has helped to create the problems of climate change, of resource extraction, of extinction. They have taken human lives away from the bubbling present in order to build an imagined, transcendent future (Bauman and $O^{\prime} B r i e n ~ 2019$, p. 112).

This chronological time when projected backwards onto history from the perspective of the colonizer creates a tunnel of time. This tunnel imposes a colonial narrative on the face of the planet that moves from the Ancient Greeks, through the dark ages, and into the European Renaissance, the discovery of "America", the American Frontier, and now I would say into the Elon Musks of today, that fuel the technological and space exploration necessary for some humans to leave this planet behind. All other narratives and events must be incorporated into or effectively erased from this narrative (like the dark ages which cover over the Arabic/Muslim influences of the rise of modern science; the erasure of indigenous peoples through slavery, forced migration, genocide, and taking over of their lands under the banner of "terra nullius", or the "Orientalism" that sees East, Southeast, and South Asia as resources for invigorating the continuation of the euro-western narrative) (Mignolo 1995). The discourse of the pre-modern, modern, and post-modern also continues this narrative, which is precisely why I attempt to articulate an alternative in the form of a critical planetary romanticism for the Earth.

The tunnel of time also underwrites the narratives of evolution that place Europeans at the "top" of the evolutionary ladder, and the anthropic narratives of the universe that suggest that humans are the most complex creatures in all the universe. From this perspective, the 13.8 billion year process of cosmic expansion has been about us (Sideris 2017). This "tunnel of time" is the result of looking back into history from a presentist perspective and re-narrating everything up to one's own culturally, socially, biologically located point. One is more or less successful at containing all histories under one narrative, the closer s/he is to the center's definition of "the norm." In other words, those that have more power in the globalized world, have more power to reinforce their narrative across the face of the globe. This is the violence of the "tunnel of time".

Teresa Brennan's book Globalization and its Horrors: Daily life in the West describes this tunnel of time (Brennan 2003), and how since the "great acceleration" of WWII (or the increase in speed of the technologies of production, communication and transportation through fossil fuels), this time is outstripping the regenerative capacities of the planetary community (McNeill and Engelke 2014). In other words, the tunnel of chronological time is now so sped up-think flying, cell phones, instant information through the internet- that just by living our daily lives, we are living outside and beyond the times of the planet. What does it mean that 100 years ago, most people's lives were limited by travel and information to a smaller space and fewer possibilities, as compared with today when more and more people are "urban" and have more access to information, possibilities, and moving about the planet? Does this time propel even our hopes and dreams beyond the carrying capacity of the planet? What are the effects of this tunnel of time on the planet and the different bodies therein? Such questions take time to answer and require a complexity that the "tunnel of time" will not allow for. Perhaps this slowed down time of the current global pandemic will give space for slowing down to think about the pace of daily life in Modernity. The tunnel time, Chronos, pairs well with and depends upon an understanding of efficient causality (not complex causality), and humans as the only real agents on the planet. 


\subsection{Efficient Causality: Isolated Agency}

Aristotle proposed four different types of causality—material, efficient, formal and final—and these were largely narrowed to one through the long, ongoing processes creating the Mechanized Organism and the reductive productive model of science. Efficiency isolates agency to the individual, and is much faster, cleaner and easier than looking at the more diffuse causality found in its formal and final senses. Everything must be assessed, measured, and have specific, efficient outcomes that lead to technology transfer and economic gain. This type of causality is largely what also gives us our sense of individual responsibility that is at the heart of Lockean Liberal economics and our legal systems in the US. In Locke's first Treatise, there is a long exegesis of the Genesis 1 narrative that focuses on what the imago Dei means. This was the period of the Glorious Revolution, and Locke was arguing against Robert Filmer, who interpreted the Genesis narrative as supporting monarchy. For Locke, instead, it meant that each and every individual has the essential right to be self-directed, we are all, in a sense "little gods" or little monarchs (Bauman 2009). Though Locke challenged the social system of monarchy and argued for rule by the people, he failed to critique the anthropology behind monarchy, that of the power-filled, isolated individual (which in turn has links with the omni-God who creates ex nihilo). Instead, everyone becomes their own little monarch. With our own isolated agency, we can then turn "dead, empty matter" into useful private property by mixing it with our labor. This making of matter dead, and humans as agents, requires a type of human essentialism. Locke thought that most people-women, black slaves, native peoples-should be counted in the category of human, except for those who were atheists-presumably because the foundation for the isolated, agency filled, individual is a creator deity. This type of essentialism denies some persons of humanity, while creating a boundary that also justifies human exceptionalism. The boundary between human and animal is policed both on the human side (through excluding some humans) and on the animal side (claiming that language, technology, or something else is reserved for only humans) through the logic of essentialism and exceptionalism. This is evident in terms of what counts as "nature" in modern thought.

\subsection{Essentialism and Exceptionalism: Humans as the Only Agents that Matter}

What do you think of when you think of "nature"? That is the question I ask my undergraduate students on the first day of the semester every time I teach my "Earth Ethics" course. Invariably, I get similar answers from my students: blue skies, whales, the ocean, trees, animals, wilderness. Very rarely do I get human beings, and almost never technology and the very buildings we live in. This is human exceptionalism. If we and our technologies are not of nature, then are we aliens? The driving question of the course is: how have we thought and felt and hoped our ways out of the rest of the planetary community, and how might we think, feel and hope ourselves back in?

There is a two-part process on the road to human exceptionalism: first you have to make a delineation between humans and non-humans (as mentioned above). The now infamous critique by historian of science and environmental historian Lynn White Jr. argued that the idea of "human dominion" in Genesis was to blame for human exceptionalism in the western world (White 1967); that same Genesis narrative that Locke used to justify individual private property, which I spoke of above. The last 50 years of the field of "Religion and Ecology" has rendered White's reading more complicated and complex, but the basic idea still remains. Whether it is the imago Dei, Reason, the Cogito, the capacity for language, technology use, self-reflexive consciousness, or the capacity for religious experiences, many scientists, philosophers, and theologians have tried to consistently maintain the uniqueness and specialness of human beings through an essence that makes us different from the rest (Peterson 2001).

The second part of human exceptionalism is then the demotion of all else toward human ends. This is what Val Plumwood calls "ethical" anthropocentrism (Plumwood 2002). Plumwood argues that we should all admit to being epistemically anthropocentric: we are embodied humans and can only see the worlds in which we live from that perspective. However, this epistemic location does not have to mean "ethical" anthropocentrism, which is rating all reality by whether or not it is beneficial or 
useful to human beings. It is this latter bit that suggests all things must fit into human history, and even then into western Modernity's version of history. It is this ethical anthropocentrism that suggests the rest of the natural world is "standing reserve" for efficient use toward human ends (Heidegger 1976).

With the technologies of, chronological time, efficient causality, and human exceptionalism, the world is created toward human ends; well, at least some humans' ends. The enlightenment, civilizing mission, cultivation of "empty" lands, and economic development are all narratives that use these technologies to recreate the world into a specific image, and to a large extent ignore the problems and violence that this re-creation causes. This vision requires no hope or faith, because it is the only path forward from the present. Except it is no longer viable. Fewer and fewer people benefit from this vision and those abjected by it and those who suffer by it are making their voices known. The rhetoric against the $1 \%$ is a testament to this unrest. Furthermore, climate change is a result of this fossil-fueled understanding of time (and corresponding technologies of human exceptionalism). As more and more begin to experience the effects of mass economic inequity and climate change, this narrative sews more and more doubt, and people begin hoping for a viable alternative that is better for the planetary community. I argue that we need new technologies that will bring about a more flourishing and a more equitable and just planetary future.

\section{Technologies of Faith and Ambiguity for the Planetary: The Organismal Machine (Poiesis)}

Perhaps a "silver lining" of climate change and the social and environmental problems we are facing in this era of climate change and neo-liberal globalization is that, like the ouroboros, the Anthopos and its Antrhopocene is devouring its own tail, creating chaos all around. This may not seem like a silver lining at all, but it may also lead to the recognition of our planetary embededdness. We are not in control; we are parts of a larger, open, indeterminate and ever-evolving complex planetary community. And, we do not know what to do. We may know some things not to do, but no one knows what lurks around the next IPCC report, or how any given action will ripple out into unknown consequences. We must, as Donna Haraway argues, stay with the trouble (Haraway 2016).

These conditions of uncertainty actually allow for critical faith and critical hope to return to our humanity. Before the universe fizzles out (as in current standard models), and before the sun expands outward and then burns out and burns the earth up along with it, and even before the worst of climate change exacerbates all of our social and ecological ills beyond what we can even imagine now, we are here, and we can still act. Faith and hope have to be about the close up and the near (Latour 2005). Faith and hope must take planetary grounds. There is a sense then, as Kyle Powys Whyte argues, that we have much to learn from those who have already experienced apocalypses (Whyte 2018). Indigenous peoples who have experienced genocide and colonization, or those whose worlds were destroyed by slave trafficking or genocides, these are peoples who have lived through and are living after the apocalypse. How do we create worlds out of the ashes of the old ones? How do we live through what seems like the end of the world? It is, I would argue, partly about doing the palliative care required to put the ailing Mechanical Organism to rest, and figuring out how to be midwives for more Organismal Machines. What might technologies of the planetary, or what we might also call Organismal Machines, even look like? Unlike a mechanical organism, which imposes mechanics upon the planetary systems, an organismal machine, models the planetary systems in order to create planetary technologies.

\subsection{Planetary Times: Reverberation, Spiraling (Queering)}

If the tunnel of time, Chronos, takes us out of our own and other planetary bodies, then perhaps a planetary time should take account of the multiple experiences of the planetary community. One such re-imagining can be found in the speculative scientific idea of "Rainbow Gravity". In this theory, there is no beginning to the universe: no big bang, no creation ex nihilo. Further, there is a kind of particle-based perspectivism according to this theory. As one article puts it, "The color of light is determined by its frequency, and because different frequencies correspond to different energies, light particles (photons) of different colors would travel on slightly different paths through spacetime, according to their energy" 
(Moskowitz 2013). Different frequencies, different paths through spacetime-different embodiments, multiple ways of becoming. This is highly speculative, but speculation is precisely what helps us materialize different ways of becoming. We need different stories about possible beginnings and possible future becomings in order to break out of singular historical narratives. We need spectral thinking in order to discern the spectrum of possibilities. Our seizing of alternative possibilities for how we might want to become as a planetary community must include speculation, or we will be adrift in spacetime unaware of the grounds on which we stand.

Religions are full of examples of different times: meditation, yoga, contemplative, and many mystical practices attempt to get us into a different way of understanding our time that helps slow us down so we might recognize our relatedness to planetary elements and bodies. The ideas of dreamtime or sacred time also have nothing to do with Chronos. Might we also be able to extend these experiences of different times to different entities and organisms? We might talk about the times of trees, of rivers, of bees, or of polar bears; the times of glaciers and whales and sea turtles; the time of the mosquito, the flea, and the nematode. Different bodies in the world demand different times: one size does not fit all.

This understanding of multiple times also implies that there are multiple worldings, together all of which at any moment might make up what we call the open planetary system. It is not closed, and there is not a central world to which all of our worlds are attached, but taking a page out of a modified understanding of perspectivism (Viveiros de Castro 2012), there are many different planetary worlds being co-constructed (human and non), as Latour might argue collected (Latour 2004), at any given moment. It is the sum of these worldings that we might call the planetary. Such an understanding of time also calls for a different understanding of agency and causality.

\subsection{Multiple Causality and Distributed Agency: Formal, Final, Material, Efficient}

If efficient causality helps keep us locked into Liberal understandings of action, and also into a human-centered understanding of agency, then perhaps what is called for from a planetary perspective is distributed agency. Animisms, New Materialisms, and other immanent traditions within religions and newly emerging immanent ways of thinking also suggest this type of distributed agency. These planetary relationalities suggest that the reasons you are reading this article have a lot more to do with other agents and actants than with your own individual decision to do so. The formation of the planet, breathable oxygen, the bacteria and other organisms that make up the microbiomes of our bodies, the evolutionary flows that led to the development of our opposable thumbs, the cerebral cortex, the other flora and fauna we have co-evolved with, the relatively stable climate and related oceanic currents we have experienced over the last 10,000 years that have allowed for human civilizations and all we think of as "culture" to emerge, the time in which we were born, the sex, race, gender, sexuality, economic class, and other identities that are privileged (or not) depending on which societies we come from, the deep affects that structure what we understand as good, true, and beautiful, the languages we are born into and/or learn, the infrastructure that forces how we move energy, materials and information around the planet, the technology that went into my Macbook that produced this article, and the internet without which you probably would not be reading this. These are all agents that make our own agencies possible, narrow our own fields of agency and/or persuade our agencies to choose this or that in any given decision process.

My friend and colleague Mary Keller in her work on "spiritual possession" within Afro-Caribbean religions has developed an understanding of diffused agency that illustrates this way of thinking in regards to climate change (Keller 2019). Instead of thinking that we are in any sort of control to fix the problems we created, she argues that we are all possessed by fossil fuels; climate change is the demon of that possession. We must listen to what this demon is trying to tell us if we are ever going to see the demon leave our bodies. This is a radically different approach to understanding ourselves, one which acknowledges we are not in control. We must appeal to the gods, to ancestors and other ghosts, and to other planetary spirits and creatures in order to get help, in hopes that we might co-create different 
worlds in the planetary future. We have to live without certainty, and instead in the spacetime of planetary faith and hope.

\section{Planetary Creatures, Planetary Citizens, and the Planetary Polis}

As my friend and colleague James Miller often quips in conversations, "It doesn't take a village, it takes a planet to make a person." Coming from his reading of the porous, fluid understanding found in Daoism, he argues, against histories of exceptional thinking, and instead that this planet is not made for us, but rather that it makes us (Miller 2017). We are dependent upon it, not the other way around. Recognition of this deep, planetary dependency is something newly emergent, for we have not lived in this globalized world in which we know so much about the entire planet until very recently. This does not mean there are no other traditions that have focused on this dependency: dependent co-arising in Buddhism, many indigenous animisms and shamanisms, Daoist, and Jain ways of thinking, among many others, have understood this in relationship to the "worlds" those thought systems inhabit, but it is only with the globalized world that we can get the type of understanding that Marcos of the Zapatista Army in Chiapas, Mexico argued for. He argued not for hope of a new world, but to live in a world of worlds (Mignolo 2011). Worlds within worlds, that is the reality of a relational, planetary human in which the human becomes, provincialized. Important to this idea is how these worlds relate and at any given moment that relation makes up what we might call the overall planetary community. There is no single "world," to which these other worlds are fitting into, but the relationships of these worlds, like the microbiomes and ecosystems and climate that make up our own worlds, make up that moment by moment manifestation of the planetary community. My hope is that this from this worlded, grounded understanding, a planetary polis (of sorts) will emerge where we can talk about what types of worlds and what types of planetary communities we want to think and act towards.

The hope here is not a hope that "looks forward" naively from the present. If the opposite of hope and faith is certainty, then a hope that looks forward often uncritically recreates the future from the present and all that goes along with it. "Things will be ok," and "Things will get back to normal" often mean a return to what has already been. If we take Walter Benjamin's metaphor of the Angel of History, facing backwards, being blown into an unknown future, while looking at all the catastrophes that build up in the name of progress, then we might understand hope as a building up of different worlds, from the ashes of the catastrophes of other worlds into an unknown future (Benjamin 2009). From this perspective, hope is an undoing of the violence of the technologies of the mechanistic organism, from within. We need to practice then, what Jack Halberstam calls "The Queer Art of Failure" (Halberstam 2011). If the success of the fossil-fueled system of the Anthropocene, and all the technologies that support it, are the problem, then we need to fail, not be successful. As Ed Abby might say, we need to practice monkey wrenching, to take apart the system from within. This also means paying deep attention to the worlds and all therein that we are losing. Hope is not for the present to be as it is in some sort of future state that is better, but hope for different worlds to come. As Jonathan Franzen wrote in the New Yorker,

Instituting humane immigration policy, advocating for racial and gender equality ... supporting a free and independent press, ridding the country of assault weapons-these are all meaningful climate actions. To survive rising temperatures, every system, whether of the natural world or of the human world, will need to be as strong and healthy as we can make it. (Franzen 2019)

This is the type of faith and hope that is still possible in most of the worlds in which we live. I do think it is, perhaps through these "little moves against destructiveness" (though these are not so little) that we can still hope for a different future to be built out of the ashes and rubble of the Anthropocene (Bedford 2001). 


\section{Coda: From Family Farm to Solar Fields}

Actions that do not seem so obvious or possible from the present moment can emerge in the processes of building different worlds. When I think about growing up on that family farm, as a child, I could have never imagined that it would one day be a solar field (See Figure 2). This is part of what it means to live in faith and hope for a different (and hopefully better) planetary future. This is no return to paradise, nor is it business as usual. It is something different that emerges out of the planetary present. There is technology involved, but it is renewable technology that listens to the demands of those voices who have been destroyed by fossil fuels. It will come with its own problems, such as the destructive mining of lithium needed to power the green, renewable revolution. But, in all this, it is a different possibility for living that may bring about more justice and flourishing for the planetary future. The fact that solar fields exist on a former soybean farm just outside of Stuttgart, Arkansas, (USA) is a major (re)attuning to the world that has taken place in my lifetime. It may be too little too late for many of our extant worlds, but the fact that this former unimaginable has now been made not only possible, but real, gives me faith and hope for a different planetary future.

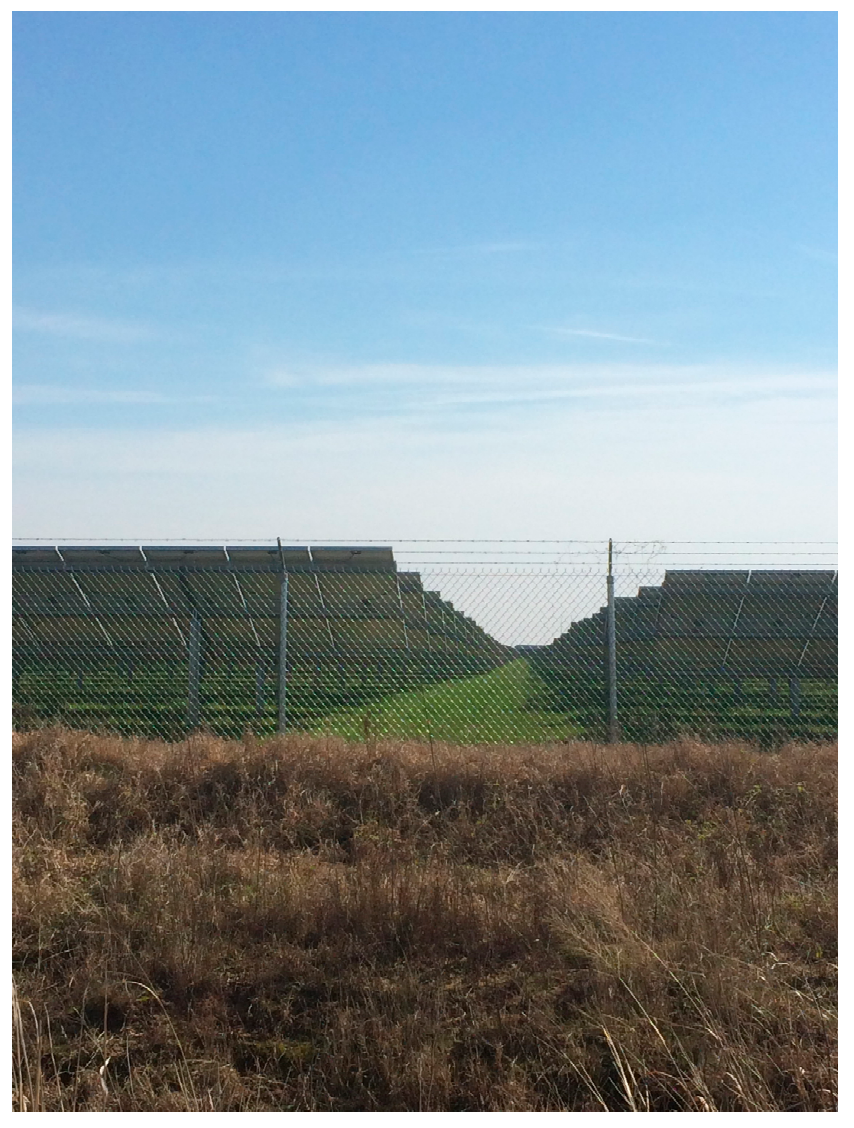

Figure 2. Solar Fields on the former Goodwin-Bauman Farm.

Funding: This research received no external funding.

Conflicts of Interest: The author declares no conflict of interest.

\section{References}

Bauman, Whitney. 2009. Theology, Creation and Environmental Ethics: From Creatio ex Nihilo to Terra Nullius. New York: Routledge.

Bauman, Whitney, and Kevin O'Brien. 2019. Environmental Ethics and Uncertainty: Wrestling with Wicked Problems. New York: Routledge. 
Bedford, Nancy. 2001. Little Moves Against Destructiveness. In Practicing Theology: Beliefs and Practices in Christian Life. Edited by Miroslav Volf and Dorothy Bass. Grand Rapids: Eerdmans, pp. 157-84.

Benjamin, Walter. 2009. On the Concept of History. New York: Classic Books.

Brennan, Teresa. 2003. Globalization and its Terrors: Daily Life in the West. New York: Routledge.

Franzen, Jonathan. 2019. What if We Stopped Pretending. The New Yorker. September 8. Available online: https: //www.newyorker.com/culture/cultural-comment/what-if-we-stopped-pretending (accessed on 3 April 2020).

Halberstam, Jack. 2011. The Queer Art of Failure. Durham: Duke University Press.

Haraway, Donna. 2016. Staying with the Trouble: Making Kin in the Chthulucene. Durham: Duke University Press.

Heidegger, Martin. 1976. The Question Concerning Technology and Other Essays. New York: Harper.

Ivakhiv, Adrian. 2018. Shadowing the Anthropocene: Eco-Realism for Turbulent Times. Earth, Milky Way: Punctum Books.

Keller, Mary. 2019. The Spirit of Climate Change. Paper presented at the International Society for the Study of Religion, Nature and Culture Meeting, University of Cork, Cork, Ireland, June 14.

Latour, Bruno. 2004. The Politics of Nature: How to Bring the Science into Democracy. Cambridge: Harvard University Press.

Latour, Bruno. 2005. Thou Shall Not Freeze-Frame, or How Not to Misunderstand the Science and Religion Debate. In Science, Religion and the Human Experience. Edited by James D. Proctor. Oxford: Oxford University Press, pp. 27-48.

McNeill, John Robert, and Peter Engelke. 2014. The Great Acceleration: An Environmental History of the Anthropocene since 1945. Cambridge: Harvard University Press.

Mignolo, Walter. 1995. The Darker Side of the Renaissance: Literacy, Territoriality, and Colonization. Ann Arbor: University of Michigan Press.

Mignolo, Walter. 2011. The Darker Side of Western Modernity: Global Futures, Decolonial Options. Durham: Duke University Press.

Miller, James. 2017. China's Green Religion: Daoism and the Quest for a Sustainable Future. New York: Columbia University Press.

Moore, Jason. 2016. Anthropocene or Capitalocene?: Nature, History and the Crisis of Capitalism. Oakland: PM Press.

Moskowitz, Clara. 2013. In a 'Rainbow' Universe, Time May Have No Beginnning. The Scientific American. December 9. Available online: https://www.scientificamerican.com/article/rainbow-gravity-universebeginning/ (accessed on 3 April 2020).

Peterson, Anna. 2001. Being Human: Ethics, Environment and Our Place in the World. Berkeley: University of California Press.

Plumwood, Val. 2002. Environmental Culture: The Ecological Crisis of Reason. New York: Routledge.

Sideris, Lisa. 2017. Consecrating Science: Wonder, Knowledge, and the Natural World. Berkeley: University of California Press.

Viveiros de Castro, Edwardo. 2012. Cosmological Perspectivism in Amazonia and Elsewhere. Manchester: HAU. White, Lynn. 1967. The Historical Roots of Our Ecologic Crisis. Science 155: 1203-7. [CrossRef] [PubMed]

Whyte, Kyle Powys. 2018. Indigenous Science (fiction) for the Anthropocene: Ancestral Dystopias and Fantasies of Climate Crises. Environment and Planning: Nature and Space 1: 224-42. [CrossRef]

(C) 2020 by the author. Licensee MDPI, Basel, Switzerland. This article is an open access article distributed under the terms and conditions of the Creative Commons Attribution (CC BY) license (http://creativecommons.org/licenses/by/4.0/). 